\title{
Economic potential and marketing trend of bamboo in Nepal: A case study from Rautahat District
}

\begin{abstract}
R. K. Jha ${ }^{1,2}$ and J. N. Yadava ${ }^{1}$
Bamboo is a versatile gift of nature. It has direct link to the socio-economic and cultural conditions of the Nepalese people. The aim of the study was to assess the status of bamboo production in private land, its contribution to socio-economic condition and marketing trend of bamboo culms and bamboo products. This study was conducted in 10 Village Development Committees (VDCs) of Rautahat District during July to October, 2010. Data were collected through household $(\mathrm{HH})$ survey using semistructured questionnaires, key-informant survey through interviews, focus group discussion, market survey, and bamboo stock measurement. Two wards in each VDC were selected purposively based on availability of bamboo. The HHs in the selected wards were categorized into three well-being classes (rich, middle and poor) through participatory approach. The average number of bamboo clumps per $\mathrm{HH}$ was found to be 3.4 in the three categories of $\mathrm{HHs}$ within the study area; 5.7 (highest) in the rich-class $\mathrm{HHs}$ followed by 3.9 in the middle-class $\mathrm{HHs}$ and 0.5 (lowest) in the poorclass HHs; there were, on an average, 80 culms per bamboo clump in the study area. On the contrary, the income from the bamboo sector was found to be just opposite$73.85 \%$ in the poor-class $\mathrm{HHs}$ followed by $2.37 \%$ in the middle-class $\mathrm{HHs}$ and $0.85 \%$ in the rich-class HHs. The prices of bamboo culms, basket and Nanglo winnow were found to have increased by $51.6 \%, 41.0 \%$ and $36.4 \%$ respectively during the last 4 years- from 2006/07 to 2010 . No fixed market, no fixed price and no guarantee in sealing the products were found to be the major problems for market development of the bamboo products in the district. Awareness-raising through trainings and studytours on plantation techniques to the bamboo-growers as well as the craft-makers and production of high-prized products are essential for increasing bamboo plantations and for the development of bamboo market in the district so as to make bamboo-culm supplier in the near future. The findings of this study will help the concerned agencies to inform about the status and future prospects of bamboo sector in the district.
\end{abstract}

Key words: Bamboo culms, bamboo clumps, marketing, price trend, socioeconomic, livelihood

$\mathrm{B}$ amboo is an integral part of forestry and the backbone of Nepal's rural culture (Das, 2002). It is one of the important renewable natural resources that can bring people above the poverty line if grown and managed on a sustainable basis (Das, 2002; Poudyal and Das, 2002); the importance of bamboo in the predominantly agricultural economy, particularly the rural economy of Nepal is well recognized (Bista 2004; Das 2001; Karki et al. 1998; Karki and Karki, 1996; Storey, 1990). Bamboos are in great demand among the rural people for construction materials. They are equally demanded by bamboo artisans and the rural as well as the urban enterprises for making various bamboo products and for a host of household uses including weaving. In terms of utilization, weaving of bamboo strips is most popular, as $70 \%$ of the farmers grow bamboo on their farms and around the homesteads for the purpose (Karki, et al. 1998). Thus, bamboo-based enterprises are some of the options to reduce poverty by creating employment for both the rural and urban work-force (Karki and Karki, 1996).

Farmers grow bamboo in their private farmlands (Das, 2002). It has been introduced in many community forests adopting the traditional methods of production, management and

${ }^{1}$ Institute of Forestry (IoF), Tribhuvan University (TU), Hetauda, Nepal, Email: rajeevk.jha2010@yahoo.com

${ }^{2}$ Department of Forest Reseach and Survey, Kathmandu, Nepal 
marketing of their products (TIS, 2004). Most producers are poor and cannot venture for commercial production and marketing. The ethnic communities of Panjiyar of the hill-origin and Dom and Mahali of the Terai-origin heavily depend on bamboos for their survival (Das, 2002). Most of the marginalized people like Magar, Chepang, Tharu, Dalits (e.g. Dom, Dushad and Mushar) are involved in bamboo crafts in the Terai region (Adhikari, 2008). These people make different types of bamboo woven-products, handicrafts, and furniture for their income. These locally-produced bamboo products are readily bought and sold in the local market, but its trade is not satisfactory in the national market due to the lack of transportation network and well-established marketing system (Adhikari, 2008). Marketing of bamboos and their products (bamboo crafts) is one of the important sources of income for the poor people, especially for the people who are socially and economically underprivileged (Das, 2002; MDBRPP/DFRS, 2010). However, only $10 \%$ of the traditionally processed products are competitive in the international market. The remaining $90 \%$ of the products face threats from other substitutes or international products (MDBRPP/DFRS, 2011).

Bamboo-based enterprises are important source of employment for both the rural as well as the urban workforce. However, due to the lack of favourable policy and government's support, disorganized market and limited skills, bamboobased economy contributes only $1-2 \%$ to the national economy (Karki et al., 1998). In Nepal, the use of bamboo has been only for subsistence, and its modern market is not well developed. However, with the growing bamboo demand in the world, abundant availability of the resources, vast traditional knowledge-base and cultural affinity of this material in Nepal, there is a tremendous potential for it to contribute to the people's livelihood (Adhikari, 2008).

It has been recognized that bamboo plays an essential role in the socio-economic development of the rural people, especially the poor (Dom, Dushad and Mushar) of Rautahat District of Nepal. So, for its overall development, more attention needs to be given for enhancing opportunities of employment as well as income generation for the specific target groups in the district. Keeping this into consideration, this study was conducted to assess the economic potential and market trend of bamboo in Rautahat District of Nepal in general, and to assess the status of bamboo production in private land, the contribution of bamboo in socioeconomic condition of the people, and marketing trend of bamboo and some of its products in particular.

\section{Materials and methods}

\section{Study area}

Rautahat District is located between 26 $44^{\prime}$ to $27^{\circ} 14^{\prime} \mathrm{N}$ latitudes and $85^{\circ} 14^{\prime}$ to $85^{\circ} 30^{\prime} \mathrm{E}$ longitudes in the Terai region of Central Nepal (Figure 1), and covers an area of 1038.12 sq. km (Survey Department, 2001). In 2010, it consisted of 96 Village Development Committees (VDCs) and one municipality, but now it comprises 94 VDCs and three municipalities. Its district headquarters is Gaur. It extends over three physiographic regions viz. i) Siwaliks (hills), ii) Bhawar (undulating land) and iii) Terai (plain), and experiences tropical and sub-tropical type of climate. Subsistence farming is the main source of income of the large portion of the population of the district. According to the CBS (2001), the total population of the district was 545,132 (Male: 282,246; Female: 262,886) in 88,162 households (HHs); and 686,722 (male: 351,079 and female: 335,643) and in 106,668 HHs in 2011 (CBS, 2012).

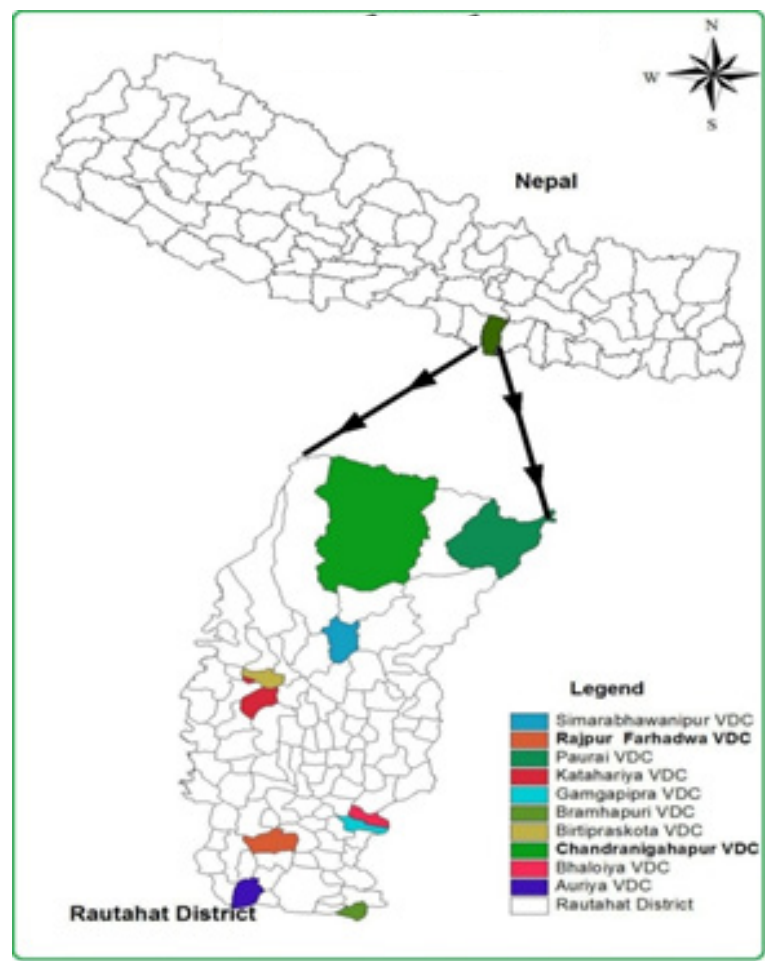

Fig. 1: Map of study area 


\section{Data collection and analysis}

Out of the total 96 VDCs of the district, ten VDCs were selected randomly through formal and informal discussion with the officials of the government as well as the non-government organizations (NGOs) and the contractors. The ten selected VDCs were Auraiya, RajpurFrahadawa, Brahampuri, Ganga-Pipra, Bhalohiya, Katahariya, Birtipraskota, Simra-Bhawanipur, Chandranigahpur and Paurai.

In each VDC, two wards (high and low bamboo stocking wards) out of nine were selected purposively by consulting the local people based on the criteria (maximum and minimum bamboo plantation area, maximum and minimum bamboo production and supply, dependence of HHs on bamboo, and condition of clumps and easy accessibility). Reconnaissance survey was conducted in July, 2010 to get information on community structure, land use type, vegetation, and other socio-economic conditions of the area.

All the HHs in the ten selected VDCs were categorized into three well-being classes (rich, middle and poor) through participatory ranking (Annex 1 ); equal number of $\mathrm{HHs}$ were selected randomly from each category to get $10 \%$ of the total HHs in each ward. Altogether, $144 \mathrm{HHs}$ (48 from each category) were selected from the 20 selected wards.

The survey of $144 \mathrm{HHs}$ through semi-structured questionnaires, key informants and five focusgroup discussions was conducted during AugustOctober, 2010 to collect data on the production of bamboo (number of clumps per $\mathrm{HH}$ ), market situation, price trend, demand and supply, uses of raw bamboo and its products together with the problems associated with its production and marketing. Altogether, 33 bamboo entrepreneurs, 10 district officials, six bamboo contractors and 30 customers were interviewed as key informants. In addition to this, various market centers in the district were visited to acquire information on market prices of raw bamboo and its products.

Altogether, five bamboo clumps were selected randomly and the clump diameters were measured at two sides (north-south and east-west) perpendicular to each other. Young $(<1$ year), middle-aged ( $1-3$ years) and mature ( $>3$ years) culms were counted from a plot $(1 \mathrm{~m} \times 1 \mathrm{~m})$ laid out at the central part of each clump.

\section{Estimation of VDC-wise bamboo production}

Step I: First of all, the area of each clump was determined using the formula:

$$
\mathrm{A}=\pi \mathrm{d}^{2} / 4 \text {, }
$$

where, $d$ is the diameter of the clump.

Step II: The number of bamboo culms per clump was estimated by multiplying the area of the clump by the number of culms per plot.

Step III. The average number of bamboo clumps per HH in each selected ward was determined by dividing the sum of the weighted mean of high bamboo stock $\left(\mathrm{C}_{1}\right)$ and low bamboo stock $\left(\mathrm{C}_{2}\right)$ as follows:

Av. no. of clumps/HH $=\left[\mathrm{C}_{1} \mathrm{~N}_{1}+\mathrm{C}_{2} \mathrm{~N}_{2}\right] /\left[\mathrm{N}_{1}+\mathrm{N}_{2}\right]$,

Where,

$\mathrm{N}_{1}=$ No. of HHs in the ward with high bamboo stock

$\mathrm{N}_{2}=$ No. of HHs in the ward with low bamboo stock

Step IV. The total number of bamboo clumps in each VDC was calculated by multiplying the average number of bamboo clumps per HH by the total number of HHs in the VDC.

Step V. Finally, the total number of culms produced in each VDC was calculated by multiplying the average number of clump per $\mathrm{HH}$ (based on the HH survey) by the average number of culms per clump (based on the plot) and then by the total number of HHs in the VDC. The data were analyzed using MS Excel and SPSS 11.2.

\section{Results and discussion}

Out of the total number of HHs (144) surveyed, $77.1 \% \mathrm{HHs}$ (111) were found to have planted bamboo on their farmlands (Table 1), of which only $9.9 \%$ had planted bamboo for self use while $75.7 \%$ had planted bamboo for self use as well as for selling. Similarly, $0.9 \%$ had planted bamboo for processing and self use, 3.6\% for processing and selling, and $9.9 \%$ for self use and all other purposes. About 23\% HHs had not planted bamboo due to either limited or no land for plantation. These HHs were involved in bamboo-based enterprises. However, the selling of the bamboo was not regular. According to the respondents, they used to sell their bamboo culms to the contractors and to some villagers at their farm gates. 
Bamboo farming and bamboo enterprise favour the development of small landholders and the use of intensive labour suited to the Nepalese quest of eliminating poverty by improving the means of livelihood of the rural poor (TIS, 2004). Therefore, bamboo farming can be a powerful tool to foster rural development.

Table 1: Purpose of bamboo growing on private land

\begin{tabular}{|c|c|c|}
\hline Purpose & $\begin{array}{c}\text { Bamboo } \\
\text { grower }(\%) \\
\mathrm{N}=\mathbf{1 1 1}\end{array}$ & $\begin{array}{c}\text { Total HHs } \\
(\%), \\
\mathrm{N}=144\end{array}$ \\
\hline Self use & 9.91 & 7.64 \\
\hline Self use and selling & 75.68 & 58.33 \\
\hline Processing and self use & 0.90 & 0.69 \\
\hline Processing and selling & 3.60 & 2.78 \\
\hline All & 9.91 & 7.64 \\
\hline $\begin{array}{l}\text { HHs without bamboo } \\
\text { clumps }\end{array}$ & & 22.92 \\
\hline Total & 100.00 & 100.00 \\
\hline
\end{tabular}

The rich-class HHs were significantly different from the middle- and the poor-class HHs in terms of bamboo-clump holding $(\mathrm{p}<0.05)$ (Annex 2). The rich HHs had higher percentage of bamboo clumps $(58.6 \%)$ than the middle-class $(37.4 \%)$ and the poor (4.0\%) HHs (Figure 2). The higher percentages of bamboo clumps in the rich and the middle-class HHs is mainly due to the availability of their land for bamboo planting.

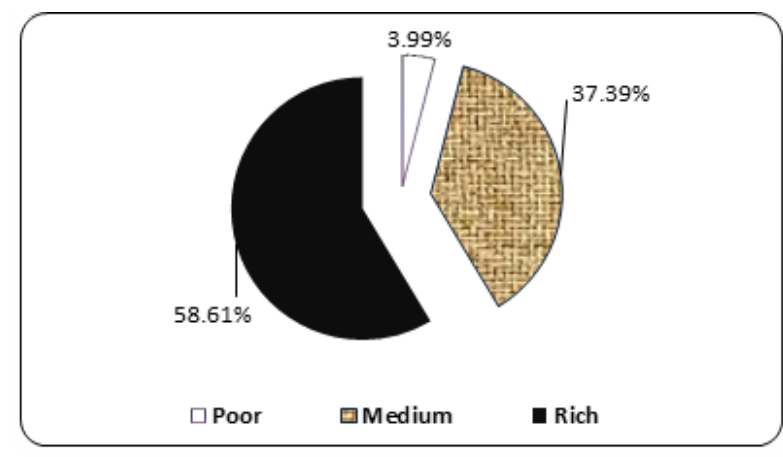

Fig. 2: Distribution of bamboo clumps by wealth categories

According to the study conducted by Das and Seely (1996) in Eastern Nepal, the levels of bamboo growing varied significantly according to wealth. The land size is directly proportional to the amount of bamboo plantation; usually, the rich HHs with large landholdings plant more bamboos than the poor HHs with less land (Karki et al., 1998). Similar findings were found in this study. Ghimire (2008) found that the richer HHs had relatively more land and had more bamboo clumps but not in significant numbers, only 2-5 clumps per household while most of the poor HHs had no bamboo clumps in their homesteads, and only some poor $\mathrm{HHs}$ had hardly $1-2$ bamboo clumps in their homesteads. The findings of this study showed that there were, on an average, 3.4 bamboo clumps per $\mathrm{HH}$ within the study area (10 VDCs); the poor HHs with 0.5 clumps per $\mathrm{HH}$, middle-class HHs with 3.9 clumps per $\mathrm{HH}$ and the rich HHs with 5.7 clumps per HH (Table 2). Bhalohiya VDC had the highest number of bamboo clumps per HH (4.67) followed by Ganga Pipra VDC (4.33) and Brahampuri VDC (3.67). Chandranigahpur and Paurahi VDCs had the lowest number of bamboo clumps per $\mathrm{HH}$ (2.33). The average number of clumps per $\mathrm{HH}$ in Paurai, Birtipraskota, Simrabhawanipur and was lower than that of overall average (Table 4). The number of bamboo clumps per $\mathrm{HH}$ varied in different VDCs (Table 2) that might be due to high population with limited lands. Based on the field survey conducted in 2010, there were, on an average, 80 culms per bamboo clump in the study area.

There was significant difference in the distribution pattern of bamboo clumps among the three categories of $\mathrm{HHs}\left[\mathrm{F}_{\text {(at } 2 \text { and } 141 \text { degree of freedom (df)) }}=\right.$ 86.02, $\mathrm{P}<0.05]$ (Table 3).

\section{Bamboo stocking}

Rajpur Frahadawa VDC had the highest stock of bamboo $(585,392)$ followed by Chandranigahapur VDC $(512,579)$ and Auraiya VDC $(392,931)$ (Table 4). Paurai, Kathaiya, Bhalohiya and Simrabhawanipur VDCs had almost equal number of bamboo culms while Britipraskota VDC had the lowest stocking of bamboo $(111,481)$, about one-fifth of the bamboo culms found in Rajpur Frahadawa VDC. The total stocking of the middle-aged culms $(1,391,469)$ and the mature culms $(1,401,238)$ were nearly equal whereas that of the young ones $(174,260)$ was comparatively quite low (Table 4). This indicates the poor management practice for bamboo. For the sustained yield of bamboo culms, the mature and middle-aged culms need to be urgently thinned so as to provide sufficient space for the young ones as well as the new shoots. It will not only provide sufficient income to the farmers but also provide better growth of bamboo in future. 
Table 2: VDC-wise number of clumps per household by wealth categories

\begin{tabular}{llrrrr}
\hline \multirow{2}{*}{ S.N. } & \multicolumn{1}{c}{ VDC } & \multicolumn{4}{c}{ No. of clumps by wealth categories } \\
\cline { 3 - 6 } & & Poor & Middle-aged & Rich & Average \\
\hline 1. & Auraiya & 1 & 4 & 7 & 4.00 \\
2. & Paurai & 0 & 4 & 3 & 2.33 \\
3. & Rajpur Frahadawa & 1 & 4 & 5 & 3.33 \\
4. & Brahampuri & 0 & 4 & 7 & 3.67 \\
5. & Ganga Pipra & 1 & 4 & 8 & 4.33 \\
6. & Bhalohiya & 1 & 4 & 9 & 4.67 \\
7. & Kathariya & 0 & 4 & 6 & 3.33 \\
8. & Birtipraskota & 1 & 4 & 4 & 3.00 \\
9. & Simrabhawanipur & 0 & 4 & 4 & 2.67 \\
10. & Chandranigahpur & 0 & 3 & 4 & 2.33 \\
\hline \multicolumn{7}{c}{ Total } & $\mathbf{5}$ & $\mathbf{3 9}$ & $\mathbf{5 7}$ & $\mathbf{3 3 . 6 6}$ \\
\hline
\end{tabular}

Table 3: One-way ANOVA showing the distribution of clumps in the three wealth categories

\begin{tabular}{lrrrrl}
\hline \multicolumn{1}{c}{ No. of Clump } & Sum of squares & \multicolumn{1}{c}{ d. f. } & Mean square & \multicolumn{1}{c}{ F } & \multicolumn{1}{l}{ Sig. } \\
\hline Between groups & 715.85 & 2 & 357.92 & 86.02 & $<0.001$ \\
Within groups & 586.71 & 141 & 4.16 & & \\
\hline Total & $\mathbf{1 3 0 2 . 5 6}$ & $\mathbf{1 4 3}$ & & & \\
\hline
\end{tabular}

Dry bamboo culms were found in all the VDCs (Figure 3) indicating urgent bamboo management practice need which is crucial for the sustainable yield of bamboo. Rajpur-Frahadawa VDC with highest bamboo stock had also highest number of dry bamboo culms $(28,691)$ followed by Chandranigahpur VDC $(25,122)$ and Auraiya VDC (19,258); Ganga Pipra VDC had the lowest number of dry bamboo culms $(7,776)$ (Figure 3).

\section{Bamboo planting methods}

Rhizome planting was the most common method of bamboo propagation in the study area. Stapleton (1987) found rhizome planting as the most common bamboo propagation method which may be due to the lack of sufficient

Table 4: Stocking of bamboo culms of different age categories

\begin{tabular}{lrrrr}
\hline \multicolumn{1}{c}{ Name of VDC } & Young $(<\mathbf{1}$ year) & Middle $(\mathbf{1 - 3}$ years) & Mature $(>\mathbf{3}$ years $)$ & \multicolumn{1}{c}{ Total } \\
\hline Auraiya & 23,078 & 184,280 & 185,573 & 392,931 \\
Paurai & 15,274 & 121,960 & 122,816 & 260,050 \\
Rajpur-Frahadawa & 34,382 & 274,541 & 276,469 & 585,392 \\
Brahampuri & 10,839 & 86,551 & 87,159 & 184,550 \\
Ganga Pipra & 9,319 & 74,413 & 74,935 & 158,667 \\
Bhalohiya & 13,235 & 105,680 & 106,422 & 225,336 \\
Kathariya & 16,916 & 135,073 & 136,021 & 288,009 \\
Birtipraskota & 6,548 & 52,283 & 52,650 & 111,481 \\
Simrabhawanipur & 14,564 & 116,296 & 117,112 & 247,972 \\
Chandranigahpur & 30,105 & 240,393 & 242,080 & 512,579 \\
\hline Total & $\mathbf{1 7 4 , 2 6 0}$ & $\mathbf{1 , 3 9 1 , 4 6 9}$ & $\mathbf{1 , 4 0 1 , 2 3 8}$ & $\mathbf{2 , 9 6 6 , 9 6 7}$ \\
\hline Average & $\mathbf{1 8 8 8 7}$ & $\mathbf{1 5 0 8 1 3}$ & $\mathbf{1 5 1 8 7 2}$ & $\mathbf{3 3 7 3 3 2}$ \\
\hline
\end{tabular}




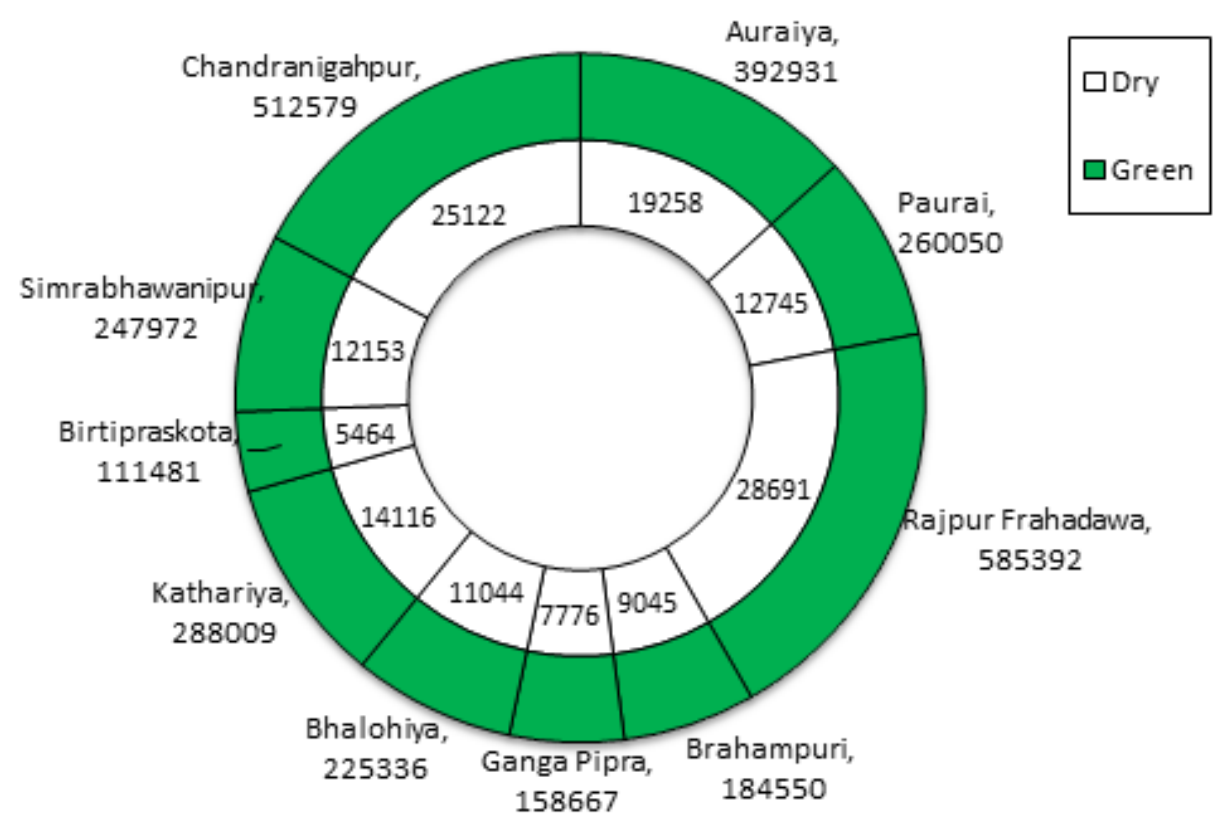

Fig. 3: VDC-wise green and dry bamboo culms

technical information to the bamboo growers (Das, 1999; 2002). Only some of the farmers $(10 \%)$ were aware of production of bamboo plants through bamboo seeds as well as bamboo culm- or branch-cuttings. Propagation through seed is technically sound method of bamboo propagation, but the propagation method adopted in the study area has not been checked so far. According to the respondents, the success rate of propagation through rhizome planting was better as they received large bamboo culms right from the beginning. However, a few farmers had introduced techniques of bamboo culm-cuttings for bamboo propagation with the technical support from the District Soil Conservation Office, Rautahat. These bamboo culm-cuttings had been planted in the degraded sites of their community forests.

\section{Bamboo harvesting}

The culms of 2-3 years of age were harvested for crafts making whereas the harvesting of the culms of more than 3 years of age was done mainly for construction purpose. In general, more bamboos were harvested during the months of SeptemberApril due to high use of bamboo culms (for making various products) in Chhath (a holly festival of the Hindus) and marriage ceremonies.

Most of the farmers (about $82 \%$ in the district) had only a few bamboo clumps $(<5)$ in their homesteads, and they had not applied any silvicultural operation in their bamboo clumps so far. It might be because of the lack of technical knowledge at farmer's level. As a result, most of the clumps were dense leading to the very limited production of new shoots due to unavailability of space in the centre part of the clump. However, people had applied some management practices on bamboo clumps, such as mounding, composting (decomposed straw and dung) and pruning during the growing stage. Such practices were only in a small-scale. Further, they had not carried out cultural operations at the later stage.

\section{Constraints in bamboo production}

Some major constraints in bamboo production in Rautahat District reported by the respondents are as follows:

* Insufficient knowledge regarding the improved method of bamboo plantation $(90 \%$ respondents),

* No subsidy provided by the government during bamboo plantation ( $83 \%$ respondents),

* Poor technical knowledge in the management of bamboo clumps ( $82 \%$ respondents),

* Obstructions from the neighboring farmers who believed that bamboo would hamper their agricultural production (94\% respondents), and

* Insufficient knowledge regarding the importance and market value of bamboo and its products (63\% respondents). 
The traditional beliefs and superstitions also affect on bamboo plantation. The common belief associated with bamboos is that it reduces the productivity of land where it grows and considerably reduces the crop productivity due to its shading-effect (Ghimire, 2008). But the agricultural land near bamboos can be effectively utilized for growing ginger (Zingiber officinalis Roscoe), turmeric (Curcuma longa Linn.), large cardamom (Amomum subulatum Roxb.), orchard grass (Dactylis glomerata L.) and dinnanth grass (Pennisetum pedicellatum Trin.) up to a distance of $11-15 \mathrm{~m}$ from the bamboo row (Singh et al., 1992, cited by Ghimire, 2008). In this study, most of the people did not know the cultivation techniques of shade-loving agricultural crops along with bamboo plantation. So, the farmers had planted only bamboos in the marginal and degraded lands, gullies, slopes and private forests. So far, the farmers had not applied agro-forestry system.

\section{Contribution of bamboo in the socio- economic condition of the people}

\section{Income from bamboo and other sources}

Bamboo was the major source of income to the poor families, contributing nearly $74 \%$ to the yearly family income. However, its contribution to the rich-class families (about $0.9 \%$ ) and middle-class families (about 2.4\%) was insignificant (Table 5). The other source of income were agriculture, business, Government/ private job and wage labour. Das (2002) reported that the total annual income from the sale of bamboo crafts, on an average, was NRs. 45,000/(NRs. $74.70=1$ US\$), around $74 \%$ of the total annual household income, for Dom and Mahali (economically poor) HHs. The finding of this research is also similar (Table 5).

Table 5: Income sources

\begin{tabular}{lrr}
\hline \multirow{2}{*}{$\begin{array}{c}\text { Wealth } \\
\text { categories }\end{array}$} & \multicolumn{2}{c}{ \% income from } \\
\cline { 2 - 3 } & Bamboo & \multicolumn{1}{c}{ Other sources } \\
\hline Poor & 73.85 & 26.15 \\
Middle & 2.37 & 97.63 \\
Rich & 0.85 & 99.15 \\
\hline
\end{tabular}

\section{Distribution of labour in bamboo enterprises}

Bamboo crafting is the traditional occupation of Dom and Chamar who are considered to be the socially as well as economically disadvantaged ethnic group in the Terai region of Nepal. More than $77 \%(n=37)$ of the poor HHs were found to be involved in bamboo enterprise and they had been producing only traditional crafts such as Nanglo (winnow), Bhakari (large storage bin), basket, fan, etc. Now-a-days, such products are facing high competition with plastics and steel products, so the entrepreneurs are not getting reasonable benefits from these goods.

Most of the HHs involved in bamboo cultivation had run small-scale enterprise throughout the year by utilizing their own traditional skills and knowledge by using their family members as the main labour source (Figure 4); sometimes exchanged and hire labour were also used. Thus, bamboo crafting had created self-employment opportunities to the family members.

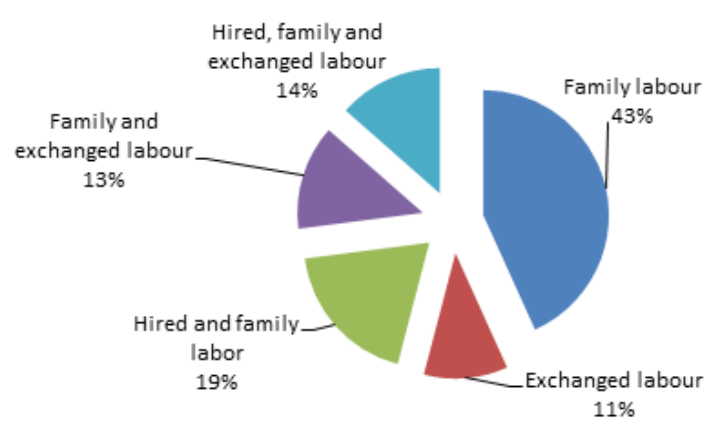

Fig. 4: Distribution of labour for bamboo enterprise $(\mathbf{N}=\mathbf{3 7})$

Men, women and children were found to be involved in bamboo enterprise; however, the proportion of time spent varied considerably (Table 6). Generally, men were involved more in crafts-making, harvesting bamboo and other silvicultural treatments. Besides, due to the lack of bamboo raw materials on their own land and the vicinity, men had to spend more time in acquiring raw materials and transporting bamboo products to the market. Women had to spend most of their time in household activities, and so, their involvement in bamboo enterprise was less as compared to men. In some families, children were also involved in bamboo enterprise, especially in transporting and selling the bamboo products in the local market. 
Table 6: Time spent by the family members in bamboo enterprise

\begin{tabular}{lrr}
\hline $\begin{array}{c}\text { Family } \\
\text { member }\end{array}$ & \multicolumn{1}{c}{$\begin{array}{c}\text { Time spent } \\
(\%)\end{array}$} & $\begin{array}{c}\text { Involvement } \\
\text { \% (N=37) }\end{array}$ \\
\hline Men & $<25 \%$ & 5.40 \\
& $25-50 \%$ & 10.81 \\
& $50-75 \%$ & 27.03 \\
Women & $>75 \%$ & 56.76 \\
& $<25 \%$ & 24.32 \\
& $25-50 \%$ & 29.73 \\
& $50-75 \%$ & 24.33 \\
Children & $>75 \%$ & 13.51 \\
& Not involved at all & 8.11 \\
& $<25 \%$ & 48.65 \\
& $25-50 \%$ & 2.70 \\
& Not involved at all & 48.65 \\
\hline
\end{tabular}

Demand for bamboo culms per household per annum

The poor families were found to have used more bamboo culms annually. They had used bamboo culms mainly for craft-making, but the use of bamboo culms by the rich and middle-class families was considerably found to be less (Table 7), which might be due to the increasing use of plastic and steel-made materials and the use of brick, concrete and cement in construction of houses. In addition to this, only poor HHs were involved in bamboo enterprise, especially in craftmaking for which, on an average, 284 bamboo culms were required per HH per year (Table 7).

Table 7: Demand for bamboo culms per HH per year for various purposes

\begin{tabular}{lrrr}
\hline $\begin{array}{c}\text { Wealth } \\
\text { categories }\end{array}$ & $\begin{array}{c}\text { Self } \\
\text { use }\end{array}$ & $\begin{array}{c}\text { Craft- } \\
\text { making }\end{array}$ & Total \\
\hline Poor & 26 & 284 & 310 \\
Middle & 23 & 0 & 23 \\
Rich & 20 & 0 & 20 \\
\hline Average & $\mathbf{2 3}$ & $\mathbf{9 5}$ & $\mathbf{1 1 8}$ \\
\hline
\end{tabular}

There was significant difference $\left[\mathrm{F}_{(\text {at } 2 \text { and } 141 \text { d. f.) }}\right.$ $=4.455, \mathrm{P}<0.05]$ in the requirement of bamboo culms for self-use between the poor and the rich HHs (Table 8 and Annex 3).

\section{Unit cost analysis of some bamboo products}

The unit cost and benefit analysis of some bamboo products (fan, Nanglo, basket and Bhakari) made by Dom HHs was performed. The income from Bhakari (NRs. 418) was more than that from the other traditional crafts (Table 9). However, according to the bamboo craft-makers, the demand of Bhakari was not that high and uniform.

\section{Price trend of bamboo culms and few products}

The price of culms increased by $51.6 \%$ whereas the price of basket and Nanglo increased by $41 \%$ and $36.36 \%$, respectively during the last four years from 2006 to 2010 (Figure 5). The price of culms increased more than that of basket and Nanglo, which may be due to the high demand of culms in urban areas of Nepal and locally for the purpose of scaffolding. According to Poudyal (1991), the demand for Tama Bans (Dendrocalamus hamiltonii) and Taru Bans (Bambusa nutans subsp. nutans) for scaffolding is quite high in the Kathmandu Valley, and the price has increased by about $300 \%$ in the past 20 years (1990-2010). This study also showed the increasing trend in the bamboo-culm price. In fact, it might be a significant increase within a short period of the last four years. Such increase in the bamboo-culm price may be due to the limited resources, high demand both in the urban as well as the local areas for house construction, and increasing transportation facilities. Similarly, the price of bamboo products also increased which might be due to the increase in labour cost as well as culms price.

Table 8: One-way ANOVA for demand for bamboo culms for self use

\begin{tabular}{lrrrrr}
\hline \multicolumn{1}{c}{ No. of culms } & Sum of squares & \multicolumn{1}{c}{ d. f. } & Mean square & \multicolumn{1}{l}{ F } & \multicolumn{1}{l}{ Sig. } \\
\hline Between groups & 1093.847 & 2 & 546.924 & 4.455 & 0.013 \\
Within groups & 17309.146 & 141 & 122.760 & & \\
\hline Total & $\mathbf{1 8 4 0 2 . 9 9 3}$ & $\mathbf{1 4 3}$ & & & \\
\hline
\end{tabular}


Table 9: Unit cost analysis of some bamboo products (price is in NRs.)

\begin{tabular}{llrrrrrrrl}
\hline S.N. & Product & $\begin{array}{r}\text { No. of } \\
\text { labour }\end{array}$ & $\begin{array}{r}\text { No. of } \\
\text { bamboo }\end{array}$ & $\begin{array}{c}\text { Quantity } \\
\text { produced }\end{array}$ & $\begin{array}{c}\text { Total } \\
\text { cost }\end{array}$ & Unit cost & $\begin{array}{c}\text { Selling } \\
\text { price }\end{array}$ & Income & Remarks \\
\hline 1 & Fan & 1 & 1 & 12 & 243 & 20.25 & 25 & 4.75 & $\begin{array}{l}\text { Rs 2 for } \\
\text { colouring }\end{array}$ \\
2 & Nanglo & 2 & 2 & 12 & 532 & 44.33 & 75 & 30.67 & $\begin{array}{l}\text { Rs 50 for } \\
\text { plastic }\end{array}$ \\
3 & Basket & 25 & 18 & 100 & 5388 & 53.88 & 85 & 31.12 & \\
4 & Bhakari & 1 & 2 & 1 & 332 & 332.00 & 750 & 418.00 & \\
\hline
\end{tabular}

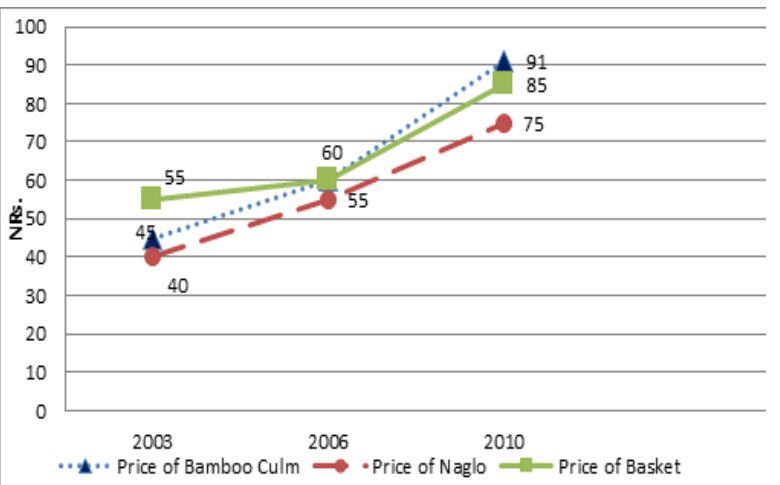

Fig. 5: Price trend of bamboo culm and its products

\section{Demand trend for bamboo culms for self use}

The trend in use of bamboo culms by rich and middle-class HHs decreased during the last seven years from 2003/04 to 2010 while there was no change in the use of bamboo culms in the poor HHs during the same period (Figure 6). The decrease in the use of bamboo culms in the rich and the middle-class HHs might be due to the influx of plastic and steel-made materials for their domestic purpose and the use of brick and cement instead of bamboos for the construction of their houses. On the other hand, the constant demand for bamboo culms in the poor HHs showed insignificant change in their family income. In 2010, the demand for bamboo culms in the rich and the middle-class HHs was found to have decreased by 10 and 7 (by number) respectively due to the increase in the family income i.e. the demand for bamboo culms for self use was impersonally proportional to the family income.

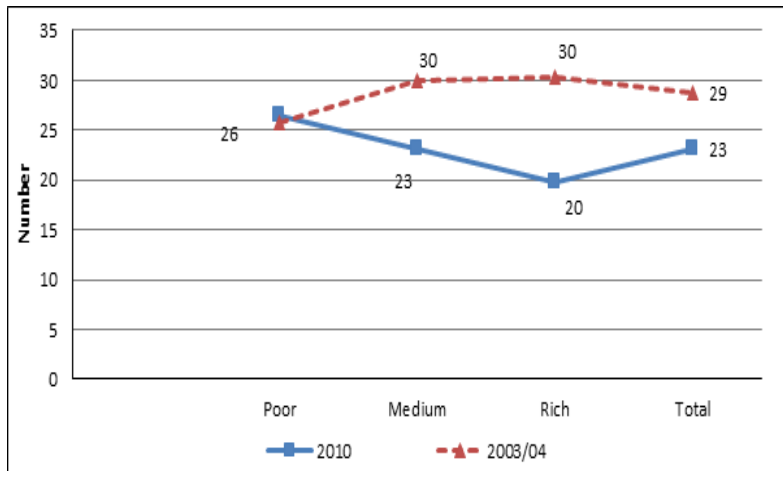

Fig. 6: Demand trend for bamboo culms in different wealth categories for self use

\section{Supply of bamboo culms}

Bamboos grown on the private lands had met the demand for bamboo culms at small-scale locally in the VDCs. The stocking of bamboo was found to be higher in the southern parts (e.g. Auraiya, Rajpur Frahadawa, Brahampuri, Ganga Pipra and Bhalohiya VDCs) than in the northern parts (e.g. Chandranigahpur and Paurai VDCs) of the District (Table 4). According to the respondents, the demand for bamboo culms was found to have fulfilled only in the southern parts of the District and not in the northern parts.

\section{Demand for bamboo products}

People in the study area had used different bamboo products for their domestic purposes. However, we collected the data related to the annual demand for basket and Nanglo per HH. The demand for basket from the poor and the middle-class HHs was the same during the last seven years from 2003/04 to 2010 (Figure 7) although the number of culms required for self use varied in these HH classes (Figure 6). Further, the demand for basket from the rich HHs slightly decreased (Figure 7). Similarly, the demand for Nanglo from the rich and the middle-class HHs 
was the same during this period. The decrease in demand of basket may be due to preference of people for plastic and aluminum materials, which do not damage easily, and there is no danger of termites and weevils.

As the average requirement of basket and Nanglo per HH was 13 and 2 in 2010, respectively, thus, the total requirement of basket and Nanglo in Rautahat District was estimated to be $11,46,106$ and 1,76,324 in 2010 respectively; the assumption is that each $\mathrm{HH}$ needs these products every year.

According to the entrepreneurs, the demand of bamboo products increased for handicrafts, and racks but the demand of traditional bamboo products decreased (Figure 7). However, the bamboo entrepreneurs are able to produce the products in demand but they are facing the problem of low income, and lack of design and technologies.

\section{Constraints in marketing of bamboo and bamboo products}

The major constraints in marketing of bamboo culms and products as stated by the respondents were lack of fixed market, lack of fixed price and lack of guarantee in selling the bamboo products (Table 10). According to them, other constraints in marketing aspects were lack of management information system (MIS), lack of institutions in marketing and lack of government policy.

According to Ghimire (2008), the major constraints in marketing of bamboo and bamboo crafts in Lalitpur District were lack of guarantee of the bamboo crafts and lack of fixed price. The constraints in marketing aspects of bamboo and bamboo crafts found in this study were similar to the constraints stated by Ghimire (2008). However, one of the major constraints found in this study was lack of fixed market for bamboo culms and bamboo products.

Table: 10. Constraints in marketing of bamboo culms and products

\begin{tabular}{lc}
\hline \multicolumn{1}{c}{ Constraints } & Percentage \\
\hline No fixed price & 13.9 \\
Lack of guarantee in selling the & 13.2 \\
products & \\
Lack of fixed market & 36.8 \\
Lack of MIS & 7.6 \\
Lack of institution in marketing & 2.8 \\
No support from the government & 0.7 \\
All & 25.0 \\
\hline Total & $\mathbf{1 0 0 . 0}$ \\
\hline
\end{tabular}

\section{Conclusion}

Bamboo farming can be a powerful means for the government to foster rural development. Bamboo farming favours the development of small landholdings and the use of intensive labour suited to the Nepalese quest of eliminating poverty by improving the living standard of the rural people. There is a high potentiality of Rautahat District in supplying large amount of bamboo culms and bamboo products provided the bamboo growers are supported by those concerned (GOs/NGOs/INGOs) for improved methods of bamboo plantation and management

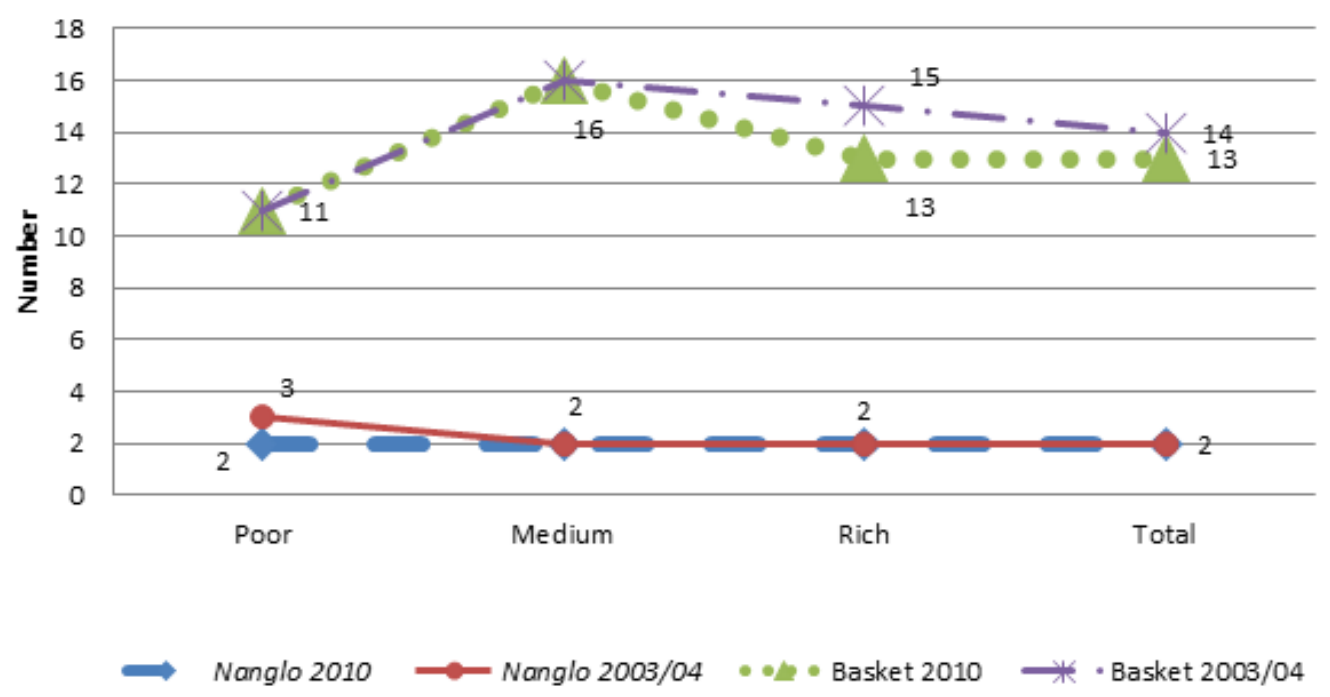

Fig. 7: Trend of demand for few bamboo products in different wealth categories 
of the existing clumps and provided the bamboo entrepreneurs are supported for training and tours on craft-making.

The price of bamboo culms is increasing day by day, and so does the price of bamboo products, but the demand for traditionally used products like Nanglo and Basket is decreasing. Besides, the demand for bamboo culms from both the rich and the middle-class families for self use purpose is decreasing. The poor families are highly dependent on bamboo for their livelihood as compared to the rich and the middle-class families. Therefore, the poor people, especially bamboo dependent ones, should be supported by those concerned in producing new modern marketing products. The bamboo dependent people are highly vulnerable to the changing market situation, and so the stakeholders have to take quick step to support them to adapt with the new market situation.

In order to improve the economic potential and marketing trend of bamboo in Nepal, the following provisions should be made by those concerned (GOs/NGOS/INGOs):

- Training on the new improved method of bamboo plantation and management of bamboo clumps should be provided to the bamboo producers, as most of the bamboo clumps are not managed well;

- As the number of young culms are less compared to the middle-aged and the mature ones, there is urgent need of silvicultural treatment in the clumps for sustained production of bamboo culms;

- Provision of study tours and advance skill development trainings should be made to the bamboo entrepreneurs for new varieties of bamboo products, as there is high demand of new varieties of bamboo products in the market and low (decreasing) demand of traditional products;

- Bamboo enterprise cooperatives should be formed for effective and efficient marketing of the bamboo products so as to support the rural livelihood;

- Bamboo income generation activities should be promoted at best by the concerned stakeholders for rural poverty reduction;

- In-depth study on the demand and supply of bamboo and its products should be carried out; and

- Bamboo products should be guaranteed for selling.

\section{References}

Adhikari, N. 2008. Economic potential of bamboo in Nepal for the traditional bamboo users in the modern economy available at (http:// abari.org/economic-potential-of-bambooinnepal). Accessed on: 20 November 2010.

Bista, D. B. 2004. People of Nepal. Ratna Pustak Bhandar, Kathmandu Nepal.

CBS. 2001. Nepal in Figure. National Planning Commission Secretariat, Central Bureau of Statistics, Ramshahpath, Kathmandu, Nepal.

CBS. 2012. National Population and Housing Census 2011 (Village Development Committee/ Municipality). Central Bureau of Statistics, Kathmandu Nepal. Volume 2.

Das, A. N. and Seeley, J. A. 1996. Bamboo use as a basis for wealth ranking in Eastern Nepal. Banko Janakari 6 (2): 89-92.

Das, A. N. 1999. Socio-Economics of Bamboos in Eastern Nepal. PhD Thesis, University of Aberdeen, U.K.

Das, A. N. 2001. Bamboo: Species for economic prosperity, environmental conservation and rural development in Nepal. Nepal Bamboo Update 2 (1): 3-4.

Das, A. N. 2002. Bamboo growing and its market development potential for sustaining rural livelihood and poverty reduction in Eastern Nepal. Banko Janakari 12 (1): 8-19.

Ghimire, A. 2008. An Assessment of the Dependency of Farmers on Bamboo Resource for Rural Livelihood in Lalitpur District, Nepal. M.Sc. BOKU University, Vienna, Austria.

Karki, J. B. S. and Karki, M. 1996 . Bamboo production, use and trade in Eastern Nepal: A Case Study. In The Role of Bamboo, Rattan, Medicinal Plants in Mountain Development (eds.) Karki, M., Rao, A. N., Rao, V. R. and Williams, J. T., 144-155. Proceedings of a workshop held at the Institute of Forestry, 
Pokhara, Nepal, 15-17 May, 1996. INBAR Technical Report No. 15.

Karki, M. B., Sherchan, G. R. and Karki, J. B. S. 1998. Extensive Bamboo Production to Consumption Systems in Nepal: A Case Study. INBAR Working Paper No. 17. International Network for Bamboo and Rattan, Beijing, China.

MDBRPP/DFRS. 2010. Review of Developed Western Markets for Bamboo and Rattan Commodities of Nepal. Market Development of Bamboo and Rattan Products with Potental (MDBRPP) Project, Department of Forest Research and Survey, Kathmandu, Nepal.

MDBRPP/DFRS. 2011. Review of Traditional Designs and Technologies of Bamboo and Rattan Products in Nepal. Market Development of Bamboo and Rattan Products with Potential (MDBRPP) Project, Department of Forest Research and Survey, Kathmandu, Nepal.

Poudyal, P. P. 1991. Utilisation of bamboo in the Kathmandu Valley of Nepal. In Proceeding of the 4th International Bamboo Workshop on Bamboo in Asia and the Pacific. Forestry Research Support Programme for Asia and the Pacific (FORSPA), Chiangmai, Thailand. Publication No. 6: 258-262.
Poudyal, S. K. and Das, A. N. 2002. Bamboo research and development in Nepal. Journal of Forest and Livelihood 2 (1): 59-61.

Stapleton, C. M. A. 1994. Bamboos, Gramineae In Manual of Afforestation in Nepal (ed) Jackson, J. K. Forest Research and Survey Centre. Kathmandu, 2nd edition, 401-427.

Storey, P. 1990. Bamboo: A Valuable Crop for the Hills. Helvetas. Kathmandu, Nepal.

Survey Department. 2001. National Topographical Base Maps. Kathmandu, Nepal.

TIS. 2004. Manual on Bamboos of Nepal. Tree Improvement and Silviculture (TIS), Natural Resources Management Sector Assistance Programme (NARMSAP), Department of Forests, Series No. 107. Kathmandu, Nepal. 
Annex 1

Checklist for wellbeing ranking

\begin{tabular}{|c|c|c|}
\hline $\begin{array}{c}\text { Rich Households } \\
\text { (high bamboo growers) }\end{array}$ & $\begin{array}{l}\text { Middle-class Households } \\
\text { (fair bamboo growers) }\end{array}$ & $\begin{array}{l}\text { Poor-class Households } \\
\text { (low bamboo growers) }\end{array}$ \\
\hline $\begin{array}{l}\text { Food (from agricultural produc- } \\
\text { tion) sufficiency for more than } \\
\text { nine months } \\
\text { Government, Corporate or } \\
\text { NGO service holder } \\
\text { Access to education } \\
\text { Landholding: more than } 2 \text { bigha } \\
\text { (1.36 ha) } \\
\text { Bank account and personal } \\
\text { saving } \\
\text { Cemented house } \\
\text { More than } 5 \text { clumps of bamboo } \\
\text { in the farm }\end{array}$ & $\begin{array}{l}>\begin{array}{l}\text { Food (from agricultural } \\
\text { production) sufficiency for 3-6 } \\
\text { months }\end{array} \\
>\text { Skilled and employed family } \\
\text { members with simple jobs in } \\
\text { government/private sector } \\
>\text { Schooling children } \\
>\text { Celebrating festivals without } \\
\text { taking loan } \\
>\text { Land holding: } 10 \text { kattha }-2 \\
\text { bigha }(0.34-1.36 \text { ha) } \\
>\text { House roofed with GI sheet and } \\
\text { wooden wall } \\
>\begin{array}{l}3-5 \text { clumps of bamboo in the } \\
\text { farm }\end{array}\end{array}$ & $\begin{array}{l}>\text { Food security }<3 \text { months from } \\
\text { agricultural production } \\
>\text { Problem in schooling their } \\
\text { children } \\
>\text { House roofed with thatch grass } \\
\text { and mud wall } \\
>\text { Dependency on wage laborer in } \\
\text { Nepal and India } \\
>\text { Difficulty in celebration of } \\
\text { festival without taking loan } \\
>\text { Land holding }<10 \text { kattha }(<0.34 \\
\text { ha) } \\
>3 \text { or less clumps of bamboo in } \\
\text { the farm }\end{array}$ \\
\hline
\end{tabular}

\section{Annex 2}

Multiple comparisons by LSD showing the distribution of clumps in 3 wealth categories

\begin{tabular}{llccccc}
\hline $\begin{array}{c}\text { Wealth } \\
\text { categories } \\
(\mathbf{I})\end{array}$ & $\begin{array}{c}\text { Wealth } \\
\text { categories } \\
(\mathbf{J})\end{array}$ & $\begin{array}{c}\text { Mean } \\
\text { difference } \\
(\mathbf{I}-\mathbf{J})\end{array}$ & Std. error & Sig. & & \multicolumn{2}{c}{$\mathbf{9 5 \% \text { confidence interval }}$} \\
\cline { 7 - 8 } Poor & Middle-class & -3.31 & 0.42 & 0.00 & -4.136 & -2.489 \\
& Rich & $-5.42 *$ & 0.42 & 0.00 & -6.240 & -4.594 \\
\multirow{2}{*}{ Middle-class } & Poor & 3.31 & 0.42 & 0.00 & 2.489 & 4.136 \\
& Rich & -2.10 & 0.42 & 0.00 & -2.927 & -1.281 \\
\multirow{2}{*}{ Rich } & Poor & $5.42^{*}$ & 0.42 & 0.00 & 4.594 & 6.240 \\
& Middle-class & 2.10 & 0.42 & 0.00 & 1.281 & 2.927 \\
\hline
\end{tabular}

*The mean difference is significant at 0.05 level

\section{Annex 3}

Multiple comparisons by LSD showing the requirement of bamboo culms for self use

\begin{tabular}{|c|c|c|c|c|c|c|}
\hline \multirow{2}{*}{$\begin{array}{l}\text { Wealth } \\
\text { categories } \\
\text { (I) }\end{array}$} & \multirow{2}{*}{$\begin{array}{c}\text { Wealth } \\
\text { categories } \\
(\mathbf{J})\end{array}$} & \multirow{2}{*}{$\begin{array}{c}\text { Mean } \\
\text { difference } \\
(\mathbf{I}-J) \\
\end{array}$} & \multirow{2}{*}{ Std. error } & \multirow{2}{*}{ Sig. } & \multicolumn{2}{|c|}{$95 \%$ confidence interval } \\
\hline & & & & & Lower & Upper \\
\hline \multirow[t]{2}{*}{ Poor } & Middle-class & 3.27 & 2.262 & 0.150 & -1.2 & 7.74 \\
\hline & Rich & $6.75 *$ & 2.262 & 0.003 & 2.28 & 11.22 \\
\hline \multirow[t]{2}{*}{ Middle-class } & Poor & -3.27 & 2.262 & 0.150 & -7.74 & 1.2 \\
\hline & Rich & 3.48 & 2.262 & 0.126 & -0.99 & 7.95 \\
\hline \multirow[t]{2}{*}{ Rich } & Poor & $-6.75 *$ & 2.262 & 0.003 & -11.22 & -2.28 \\
\hline & Middle-class & -3.48 & 2.262 & 0.126 & -7.95 & 0.99 \\
\hline
\end{tabular}

*The mean difference is significant at 0.05 level 